\title{
William Wied, Prince of the Albanians - When, Why and How?
}

\author{
Gea Sulo \\ University of Tirana \\ Faculty of History and Philology \\ Phd Research Student
}

\section{Doi:10.5901/ajis.2013.v2n9p721}

\begin{abstract}
In a short study, "Wied, The Albanian Prince, When, How and Why", are treated moments when the Great Powers took the reins to determine not only the territorial expansion but also the Status of the Albanian State. It was the Ambassador Conference which decided that Albania was constitutional autonomous principality, sovereign and hereditous under the guarantee of the latter. But, the principality wanted her own prince. Precisely those 6 Powers appointed their chosen, that after many debates was chosen Prince Wied. The following paper mainly deals with the chronological method, how Prince Wied was precisely chosen, who was, where did he came from and which stance was held in connection with his image. What were the dilemmas of Wied before he took the throne of Albania and what were his demands as warranty for these throne. In the " paper" it is comes about a short period but full of sensacional and cluttered events, which sweept almost all the Albanian territory, leaving its trace in history as scars and wrinkles in the face of the human remains. For a period when for the first time in its history, Albanians were recognized by the Great Powers, the status of an autonomes state, the status of which had fought for centuries the most prominent figures of the country. For a "period" Albania became "with of his own, his choice right way and we handled my thesis.
\end{abstract}

\section{Introduction}

November 28, 1912 is a symbolic date in the history of the Albanians, a date that put to an end the Ottoman conquest, a date that marks a fundamental turn in the destiny of the Albanians and the destiny of their state. After many centuries, it is affirmed the idea of national unity, and it happened at a time when the presence of foreign armies in the country went on. On November 28, 1912, with the proclamation of independence in Vlora, the new Albanian state started a long affectionate road. It started attempts for recognition by the great powers. Albanians wished to be recognized in the international arena together with all changes happening in their political life. They asked for the international recognition believing that they had entered in the family of the East European peoples, and underlining that their goal is to live in peace with all other Balkan states.

In the international arena, complete victory of the Balkan countries against the Ottoman armies in the Balkan conflict and the December 3, 1912 armistice between the Balkan alliance and the Ottoman government, led Balkans towards a re-composition of its borders ${ }^{1}$.

Situation created at the end of December 1912, led to the immediate necessity of the re-design borders of Balkan states that has been part of a great empire, the Ottoman one. To resolve the created geopolitical situation, it was born the idea of a conference of ambassadors that was going to discuss all problems of the time and, especially, issues that were related with the end of the Balkan War.

In this context, on December 17, 1912, in London, ambassadors of Great Powers were gathered in a meeting that was recognized as different and the Conference of Ambassadors. The only purpose of this conference, which lasted eight months, was to discuss the Balkans and its future. The conference was chaired by British Foreign Minister, Edward Grey, and participants were the ambassadors that represented Great Powers, such as France, Russia, Germany, Italy and Austro-Hungary.

During this period, the Albanian issue became an extremely important and hot topic. Conference of Ambassador took many months to discuss and decide about projects for Albania. Difficulties remained on the fact that basic projects, 
that were presented by the participating powers, remained too far apart from each other, and because compromise was too difficult, as well.

As it comes out from the reports that ambassadors sent to their governments, the Albanian issue was addressed in three main aspects. These were: the status Albania; the internal organization of the new state; and the border problem.

Consequent in their stance not to recognize the domestic factor in the organization of the new Albanian state, the Great Powers, from the first meeting on December 17, 1912, gave this issue an international character, what meant that the state apparatus will be set up by the Great Powers.

The conference reached at its final decision on 29 July 1913, under which it was recognized the independence of Albania, and it was announced an "independent Principality, hereditary and neutral, under the guarantee of the Great Powers." The conference took many important decisions that had to do with the territorial integrity of Albania. As far as Albanian territorial frontiers were concerned, for the sake of international interests, it were disregarded the interests of Albanians nationwide. Albanian lands were disintegrated and for the sake of a "compromise" Kosovo was given to Serbia and Chamëria (Çamëria in Albanian) to Greece. And the map of Albania was shaped and reduced more or less to the appearance that it has nowadays.

In early 1914, Albania continued to have a highly fragmented society, which had no clear unified political goals. Albania and its geopolitical framework itself were strange for the time. It was connected to the East by land, but steering away from the aspirations of its leaders at the time; it was far from the West so geographically close, the West that was aspired by progressive political lords of the time. Albanian feudal lords not only differed from the European ones, but they were still having characteristics of old times clans that being involved in the context of Ottoman institutions, could only govern with local laws and traditional rites, which were not written².

In the current situation, Albania was put under some international protectorate, which in fact limited the full exercise of sovereignty through a multilateral control consisted of six Great Powers of Europe, i.e. UK, France, Austro-Hungary, Germany, Russia and Italy.

This custody was taken even as a result of the then existing fears for the creation of a power gap as a result of internal weakness of the new Albanian state itself, and of the fact that it had around a very hostile Balkan reality about their lands, this because Albania has, as always, been and was at the centre of territorial goals of its near and distant neighbours.

According to the decisions of the Conference of Ambassadors, Albania was proclaimed an autonomous principality and a sovereign hereditary under the guarantee of the six great powers. Regarding the governance of the state it was decided that the leader was going to be appointed by the six great powers; it was expelled any sovereignty connection with Turkey; Albania was declared a neutral country and this neutrality was guaranteed by the six powers; prince was going to be appointed within maximum of six months; the functioning of the existing local authorities, as well as of the gendarmerie, was going to be under the control of the International Committee; the government and the public order was going to be provided by an internationally organized gendarmerie, and the constabulary officers were going to be selected among the ranks of the Swedish army... ${ }^{3}$

Appointment of foreign monarchs on top of new states was a defined solution by the European Great Powers. Before the case of Albania, the same solution was as well given to other Balkan states that had emerged independent at the end of Ottoman rule. Monarchs (being princes or kings), who was put in charge of Greece, Serbia, Bulgaria in 19th century were descendents of great European imperial or royal courts, who came here to establish a new dynasty associated with great families ${ }^{4}$.

List of candidates for the Albanian throne was too long at the very beginning. All candidates, for various reasons, met with the contradiction of interested sides. Senior officials of the Albanian provisional government, on top of which stood Ismail Qemail, tended themselves towards a prince coming from the West, an aspiration they did not hesitate to express not only to the Western Powers, but also to Constantinople.

In the impasse created, the decision for the Albanian throne was left to Austro - Hungary and Italy. Were these two powers that finally decided that Albania would have a Protestant prince of German origin, and specifically would be Wilhelm of Wied. He was going to be the Prince of Albanians and Albania was therefore going to be announced a principality and the city of Durrës was going to be its capital.

\footnotetext{
${ }^{2}$ Salleo Ferdinando, Shqipëria gjashtë muaj mbretëri, SHLK, Tiranë 2000, pp.29.

${ }^{3}$ Duka V., Histori e Shqipërisë, 1912-2000. Kristalina-HK, Tiranë 2007, pp. 57

${ }_{4}^{4}$ Puto A., Shqipëria politike 1912-1939, TOENA, Tiranë 2009, pp.119.
} 


\section{Who was Prince Wied}

His family name come from Wied, an area in Rhineland - Platinate, located on the river Wied a branch of the Rhine. Wied appeared as a county much earlier than other German shires. From 1243 until 1462 Wied was joined county of Isenburg as Isenburg - Wied.

Wied became ruler of Albanians from 7 March 1914 to 3 September of the same year, i.e. for a period of six months and is known as Wilhelm von Wied.

Wilhelm von Wied, Prince of Albanians, was born on March 26"th 1876 in Neuwied castle in Rens near Coblenz in Germany. He was baptized with the name Adolf Wilhelm Maximilian Karl, Fifth Prince, Earl of Isemberg, Lord of Rankel and Neurerburg, sometimes president of the Prussian House of Lords and a member of the German Imperial Council for Colonial Issues. He died on 18 April 1945 in Predeal, Romania.

Wilhelm was the third child, and the fifth ruler of Wieds of Germany. He was the grandson of Queen Elizabeth of Romania, his grandfather was Herman, prince of Wieds and his grandmother was princess Maria of Nassau, who was the sister of William, the Duke of Nassau.

He was married in November 1906 in Vanderburg, Saxony. With Princess Sophia of Vanderburg he had two children, Princess Mary Eleanor (1909 - 1956) and Prince Carol Victor (1913-1973) 5 .

Wied received his education at the University of Jena in Germany and served as a Lieutenant in the Royal Guard Corps of the Prussian Army. He was promoted to captain of cavalry in 1911, before he became captain of the General Staff of Germany. During his life he worked as a military and politician.

This was Wied, whom the six Powers of Europe selected at the head of the Albanian state on November 23, 1913, and who was ratified by the Albanian Provisional Government on 3 December of the same year.

If Wied won and was appointed to the post of prince of Albania, this was due to the selection of Austro-Hungary and Italy.

However it's worthy to note that the Berchold and San Giuliano (respectively foreign ministers of the two countries), initially and continually, were going to exhibit strong doubts about Wied's skills to cope with this difficult task. Both Powers stopped at Wied's candidacy because he had the advantage of being German and Protestant. It was thought that as such, during his reign on the throne of Albania, he could ensure a fair balance within the multi-religious country, and could face the contradictions between the Great Powers ${ }^{6}$.

\section{Wied's attitude about his selection}

On 3 December 1913, Prince Wied was introduced with the decision of six powers about his candidacy for the throne of Albania.

At first Vied was not shown enthusiastic to accept the throne. He knew that even the German Kaiser Wilhelm III, his cousin, was not enthusiastic. In addition, the Kaiser had expressed doubts about the Wied's personal skills to perform the mission entrusted by the Great Powers.

In his memoirs, written after the events in Albania and after the World War II, Wilhelm, Emperor of Germany, shows his doubts about the capability of Prince Wied to govern. "It was particularly unpleasant - Kaiser says - that a German prince to go and was laughing at such a place".

In a later memoir, Wied himself attempted to explain these doubts with the fact that the Emperor was essentially Grecophile, due to the effects of his sister, the queen of Greece, and brother-in-law, King Constantine.

In his life, Wied had proven to be a very capable military. In 1914, through an open competition, he was made captain of the German General Staff, but he was not familiar with Albania and never asked by himself the throne of Albania.

His candidacy was influenced mainly by his aunt, Queen Eleanor, who pushed him to accept the throne ${ }^{8}$.

Queen Elisabeth of Romania, but the queen and a writer known by the nickname "Carmen Sylva", loved her nephew so much, and pushed to her husband, King Carol, to try his best for Wied's election to the throne of Albania. To

\footnotetext{
${ }^{5} \mathrm{http}: / /$ www.royalark.net/Albania/wied.htm.

${ }^{6}$ Puto A., Shqipëria politike 1912-1939, TOENA, Tiranë 2009, pp.120.

7 Puto A., Shqipëria politike 1912-1939, TOENA, Tiranë 2009, pp.120.

${ }^{8}$ Duka V., Histori e Shqipërisë, 1912-2000. Kristalina-HK, Tiranë 2007, pp. 57.
} 
this purpose, she wrote a series of articles where she praised Wied, saying: "Romanians called Lohengrin, when he appeared in a white uniform of a bodyguard and with a silver eagle" .

Together with the commitment young Wied had shown during his studies, described him as a lad who was always seen with the books in hands, Elisabeth of Romania did not forget to describe the physical appearance of the one who would later become the prince of the Albanians.

He was described as a young officer, able to hoist with one hand any of his colleagues. He was superlatively described for his chivalric and military capabilities, as well as for his artistic talent.

Queen went so far, that with her writings, she was symbolically addressed even to the future citizens if her nephew, who "...would protect their wealth and blood ...". "It is said that the Albanians are the oldest population of Europe, the Pelasgians. Their language has no resemblance with Latin or Slavic languages. Their loyalty is so famous from ancient times. In all our countries (Romania), we have always had only Albanians, as guards of our houses, banks. Never can an Albanian be a traitor. His given word, besa, is a holy thing. Rigor in character is so great in the old homeland of men, and for this Albanians deserve to have in their forefront a holy and very beautiful family life"10.

Articles of "Carmen Sylva" have occupied the place of honour in the pages of Italian magazines, which showed their enthusiasm for "Monarch preferred by Europe". This press made comments of praise, describing a prince who was actually not known at all. ${ }^{11}$

In addition to Queen Eleanor, Wied had even the strong push of his wife, Sophia, who dreamed to emerge from anonymity and to enjoy all the luxuries and splendours of a royal court, even in the modest size of the Principality of Albania.

Despite dilemmas, on December $31^{\text {st }}$, Prince Wied answered to the communication the Great Powers asked him on December $3^{\text {rd }}$ about their decision for the throne of Albania. In this letter he wrote that:

"I really am generally prepared to accept the throne of Albania, but I cannot give a definitive answer as powers only to give their views on the conditions formulated by me, which are:

1. Since the first article of the London Protocol provides that Prince is appointed by six Great Powers, it should first be finalized the approval of my candidacy.

2. A representation of all regions of Albania must come to Germany and offer me the throne of their country.

3. Esad Pasha must give a guarantee that he recognizes the wish of Europe and that he submits the new prince.

4. Great Powers or a part of them, must guarantee a loan of $75,000,000$ francs with a banking interest of $4 \%$, which can be paid in different instalments. The first instalment must be of 20,000,000 francs.

5. Prince must receive a civic roll of 2000000 francs per year, which was an aid out of the loan.

6. The organization and administration setup of the country is a matter that must get the approval b the Prince.

7. The southern Albanian boundary must be located, at least at the main points, thus must be ruled out the possibility of arising disputes because borderline should be final.12

All points presented by Wied at first sight were reasonable given the Albanian reality, which was filled with internal problems, but was faced with external interference, as well. But the European powers were inappropriate.

According to a letter that Edward Grey sent to Foreign Office, it is stated that:

"Regarding seven points formulated by Prince, the first seems too big since the offer of great powers to grant the Crown of Albania should also have their "approval" to his candidacy. However if Prince wants a second approval, Powers may agree with his request.

Regarding the second point, in my opinion, is not in the hands of the powers to organize the representation of Albanians. Great Powers were offering the throne, and Prince should do what he thinks fit to satisfy himself, as well as the feelings of the Albanian people.

On the third point I can say that there is no reason why the Great Powers give him a special guarantee for good behaviour of Esad Pasha, although even if they wish to they are not in such positions to provide such a guarantee.

Moving on to the fourth point, which must be given definitely $4 \%$ of the debt, this is a new condition. All details of the debt must be part of other considerations, the issue of money trading at the time of issuance. Conditions set forth in paragraphs 6 and 7 appear justified. ${ }^{13}$

\footnotetext{
${ }^{9}$ Salleo Ferdinando, Shqipëria gjashtë muaj mbretëri, SHLK, Tiranë 2000, pp.54.

${ }^{10}$ Ymeri B., "Mbretëresha e Rumanisë dhe respekti i saj ndaj kombit shqiptar", http://www.zemrashqiptare.net/article.

${ }^{11}$ Salleo Ferdinando, Shqipëria gjashtë muaj mbretëri, SHLK, Tiranë 2000, pp. 55.

${ }^{12}$ Gurakuqi R., Principata e Shqipërisë dhe Mbretëria e Greqisë 1913-1914,UET/PRES, Tiranë 2011, pp. 121.
} 
Prince with his own conditions seemed to prefer waiting until the complicated situation in his future kingdom was clarified. But, the European capital cities insisted he leaves soon for Albania, where the situation was increasingly complicated. Even the Greeks, who wanted somehow a slow installation of the new regime, thought of leaving not only because they predicted that this regime was going to be weak and slow, but they also feared a military intervention of the Great Powers.

While Wied submit their requirements before the Great Powers, in a way he had decided what to do with Albania. This appears even in the records left by Duncan in his book. He describes moments when Wied was in Potsdam. He writes that on January $7^{\text {th }}, 1914$, in Potsdam, Prince really worked so much as he had not done before. He spent most of the time at his desk writing. Meanwhile, they occasionally receive many controversial voices from Albania ${ }^{14}$.

\section{Albania awaiting for Wied}

In Albania unrest continued, in places like Vlora, Elbasan, etc., but sometimes they appear even in other parts of the country. In the south, Greeks kept "Southern Epirus" occupied.

In the provisional government headquarters in Vlora intrigues between leaders had no end and this thanks to the feverish activity of Turkish agents, working to increase discontent among the Muslim population, based on the fact that a foreign Christian prince was appointed to run Albanians.

The interim government leader Ismail Qemali and Senate President Esad Pasha had a divergence, which was hardened after the discovery of a coup d'état attempt by a Ottomanophilic Beqir Aga. This forced the government attempted to declare a state of emergency. The coup d'état was aimed at toppling London's decision to open the road to one of the candidates of the crown, Izet Pasha, who immediately denied this, and this brought a game of mutual accusations. European press pointed at Esad Pasha and Ismail Qemal, who confuted it indignantly ${ }^{15}$.

Esad Pasha, although he did not deny feelings he had for Turkey, on January 13 to 14 gave interviews to the Italian newspapers and magazines, where he offered guarantee for loyalty to the selected of Europe. In the interviews, he tried mainly push Wied understand that he had the throne due to him, and that he did not give up hope that one day could become ruler of Albania. "During all your life or as long as you have not resigned from the throne - Esad wrote in a letter sent to Wied, published by the Viennese press - no other person shall be the King of Albania ... If Your Majesty will resign or die, only I can replace you".16

Meanwhile, the situation in provisional government was worsened.

On January $15^{\text {th }}$, Ismail Qemali proposed to Control Committee to take up the governance of the country. Great Powers accepted this proposal, thanking the old patriot, who sent a message even to Europeans asking them to help his brave and unfortunate people and do their best to protect their rights so little respected by enemies. After that, he took a trip to Europe via Vienna. Even Esad Pasha Toptani had promised to resign, but he pretended to. Meanwhile, he indicated that he was going to welcome Prince Wilhelm in order to present to him personally and happily the crown of Albania. Control Committee accepted the condition that Assad Pasha resign and head the delegation that would hand the crown to the prince. He received as well the promise that he would restrain his post as minister of war in the future government.

A favourable treatment of the Great Powers towards Esad is explained even by the fact that he at this turning point of the game was a key player for Albanian diplomatic issue. Around him in the backstage, a great intrigue was played in combination with very confused conflicting interests not only of the great powers, but also of the neighbouring countries. ${ }^{17}$

It may be thought that the country is finally prevailed by a period of relative calmness.

${ }^{13}$ P.R.O.F.O.371 1886 FQ.273, Sir Edward Grey to Sir F. Bertie, Foreign Office.

${ }^{14}$ Duncan Heaton-Amstrong, The six month kingdo. Albania 1914. London, NewYork I.B.TAURIS 2005, pp.49.

${ }^{15}$ Beqir Aga Grebenea, with his associates, were tried by a tribunal headed by General De Weer which came to light evidence and documents of a conspiracy led by Esat Pasha and turks. Beqir Aga was sentenced to death. Decision was suspended for the final decision to be entrusted to Prince Wilhelm when he arrived in Albania.Alpha

${ }^{16}$ Salleo Ferdinando, Shqipëria gjashtë muaj mbretëri, SHLK, Tiranë 2000, pp. 62.

${ }^{17}$ Puto A., Shqipëria politike 1912-1939, TOENA, Tiranë 2009, pp.120 


\section{Preparations for Albania}

Date of departure to Albania for Prince Wilhelm was still undefined. Again and again press published reports that push that date.

In this synoptic, Wied himself sent a delegation (von Trotha) to Durres, whose duty was to undertake preparations for the arrival of the Prince. Von Trotha was accompanied by a part of the royal family staff in order to prepare the place where coming prince was going to live. They were inspecting what was called Konaku (guest house), a building described as very old, more or less uninhabitable. Predictably, the situation was horrible since even the then newspapers were full of caricatures on the condition of the house were Wied was going to live. ${ }^{18}$

However, Von Torth said he changed konak into a place where you can live. The building had been for a long period of time and uninhabited swelling of a Turkish governor.

On 7 February 1914, the ambassadors of Austro-Hungary and Italy in Berlin informed Wied that his demands were taken into account. Meanwhile, on behalf of their respective governments, they informed that a Austro-Hungarian and Italian banking corporation, acting under the guarantees of the respective governments, was ready to decide immediately available to the Albanian government the amount of 10 million as an advance amount total loan of 75 million, of which all the Great Powers were ready to give to the Albanian government.

In these conditions, in the same day, February $7^{\text {th }}$, Prince Wied decided to accept throne of Albania. While the working group was still in Albania, Wied began what is called "Thunder Tour". He started a trip in European capitals. ${ }^{19}$

Despite the mistrust for Wied personal skills to perform the task of the Great Powers that appeared on many quarters, his travel through the capitals of six Great Powers was followed by a tight ceremony.

This tour visits is described quite masterfully by Duncan Heaton-Armstrong 20 in his publication "Six-Month Kingdom. Albania 1914". In the second chapter: Vienna - London - Paris, he describes the route of Wied in the capitals of the world.

On 9 February he left for Rome. The next day in Rome, he met King Vittorio Emanuele III, who handed the necklace Saint Maurizio and Lazzaros. There he met the Prime Minister Giolitti, and the Cardinal who was the Secretary of State of the Vatican, etc., meetings that were held at the Austrian embassy in Rome.

The Italian press of the time underlined that these meetings were not simple protocol visits, but real working meeting, where Wied was shown for a thousand problems that will emerge not only from the internal situation of Albania, but also by the diplomatic developments of the time, seeking a thin nose to maintain equilibrium. Meanwhile, it seemed that he was made known that the road to Durrës passed through Rome and Vienna.

On February $11^{\text {th }}$, he travelled to Vienna. Prince was accompanied to train station by a representative of the Austrian Emperor and a crowd of interested people. Among them was Dr. Gjergj Pekmezi, an Albanian who was described as highly cultured and a group of young people that, Duncan thinks, were educated in Vienna and were the first people that shouted "Long live the King", calls that they were going to hear when they arrived at Durrës. ${ }^{21}$

In Vienna, Wied met in a private room with Emperor Franz Joseph, meeting that is described as an unusual experience.

On February $19^{\text {th }}$, Wied arrived in Paris where his honour was admitted a dinner by the President of the French Republic gave a dinner in his honour that was attended by many dignitaries of the country. There he met with the French Foreign Minister M. Doumergue, who among other things made known to him that "It was the International Committee that was carrying the responsibilities regarding his selection made to him by the Austro-Italians. This selection will be reimbursed by Albania's international debt, and he would have to tell to the International Committee the way money was spent".22

Following meetings Wied travelled to London. At the train station he was greeted by the court's master of ceremonies, and then meetings were held in Buckingham Palace, where the prince met with the royal family. ${ }^{23}$

On February 25 Wied left Berlin for St. Petersburg, the capital of Russia. There he was initially welcomed by the assistant of the Russian Tsar, who accompanied him to the White Palace, where he met with Russian Tsar. Among other

\footnotetext{
18 "Welcome, Willie, I hope you find the palace comfortable". Cartoon from the Literary Digest, March 14, 1914

${ }^{19}$ Duncan Heaton-Amstrong, The six month kingdo. Albania 1914. London, New York I.B.Tauris 2005, pp. 51.

${ }^{20}$ Duncan Heaton-Armstrong (1886-1969), "Six-month kingdom".

${ }^{21}$ Duncan Heaton-Armstrong (1886-1969), "Six-month kingdom", pp. 51

22 P.R.O.F.F.O.371 1886 doc.no.7826 pp.402

${ }^{23}$ Duncan Heaton-Armstrong (1886-1969), "Six-month kingdom", pp. 52.
} 
things in his memory, remained even the impressions of Russian winter, Tsar's Guard Ceremony that was organized in his honour, and the appearance of the city. German Embassy gave a dinner in his honour.

Russia welcomed the prince not only to show support given to him, but to pass the message that he was mandated by all the Great Powers and not just some of them, meaning that it was not only Italy and Austro-Hungary.

Meanwhile, Russian Foreign Minister focused also on the attention Wied had to pay to the Orthodox Christian population in southern Albania. Thus he should avoid any behaviour that could lead to realize that he could be a satellite of Austria and Italy. The model advised by Russian foreign minister was the king of Romania. ${ }^{24}$

Wied left Petersburg in the following evening. At the train station he was seen off by many ambassadors accredited in Russia, together with a number of Albanians. ${ }^{25}$

From the appointment of the prince to receipt of the crown would pass two months, while his departure to Durres was done within a few weeks.

To Albania, he sailed with the Austro-Hungarian yacht "Taurus", accompanied by an international team led by the British ship "Gloucester", another reflection of their wish to have a fully controlled ruler. He departed from Trieste towards the Albanian coastline and arrived in Durrës on March $7^{\text {th }}, 1914 . .^{26}$

Now everything seemed to be ready for the big adventure waiting for Prince Wied in Albania.

\section{References}

Duka V., Histori e Shqipërisë, 1912-2000. Kristalina-HK, Tiranë 2007

Salleo Ferdinando, Shqipëria gjashtë muaj mbretëri, SHLK, Tiranë 2000

Puto A., Shqipëria politike 1912-1939, TOENA, Tiranë 2009

Ymeri B., "Mbretëresha e Rumanisë dhe respekti i saj ndaj kombit shqiptar", http://www.zemrashqiptare.net/article.

Gurakuqi R., Principata e Shqipërisë dhe Mbretëria e Greqisë 1913-1914,UET/PRES, Tiranë 2011

R.O.F.O.371 1886 FQ.273, Sir Edward Grey to Sir F. Bertie, Foreign Office.

Duncan Heaton-Amstrong, The six month kingdo. Albania 1914. London, NewYork I.B.Tauris 2005 